\title{
Bilateral J-curve between Sri Lanka and its major trading partners
}

\author{
W T K Perera ${ }^{1 /}$
}

\begin{abstract}
It is widely believed that the short run effect of exchange rate depreciation on trade balance is different from the long run. In the short run, first, the trade balance deteriorates before resulting in an improvement, suggesting a J-curve pattern. Most of the empirical studies have employed aggregate trade data, while recent studies have used bilateral trade data. These studies are mostly between industrial countries, a few developing countries, but none so far for Sri Lanka. Hence, in this study, the impact of real depreciation of Sri Lankan Rupee (SLR) on the trade balance in the short run and the long run has been examined, employing bilateral trade data between Sri Lanka and its six major trading partners using the autoregressive distributed lagged (ARDL) model. The results reveal that the trade balance between Sri Lanka and its trading partners does not support the J-curve phenomenon, and also it does not have any specific pattern in response to depreciation of real exchange rate.
\end{abstract}

\section{Introduction}

Exchange rate devaluation is one of the important policy tools that can be adopted in open macroeconomics to improve a country's competitiveness as well as the trade balance. According to the Marshall-Lerner condition, currency devaluation may succeed in improving the trade balance in the long-run, if the sum of export and import elasticities

1/ The author wishes to thank Dr. Satish Chand of the Australian National University for his valuable comments and guidance throughout this study. The views expressed in this paper are the author's own and do not necessarily reflect those of the Central Bank of Sri Lanka. 
becomes greater than unity (Bhamani-Oskooee et al. 2006). Policy makers closely follow this condition before making decisions. The intuition behind this elasticity approach is that due to currency devaluation, exporters have a chance to earn more money when they convert foreign exchange earnings form exports into domestic currency. At the same time, importers have to pay more in terms of domestic currency for imports. Hence, currency devaluation encourages exports and discourages imports. This is expected to improve the trade balance. Nevertheless, the impact of exchange rate devaluation on the balance of trade is not instantaneous (Arora et al. 2003). It is widely believed that currency depreciation worsens the trade balance in the short-run, but improves it in the long-run. As this represents the shape of the letter J, Magee (1973) named this the 'J-curve phenomenon'.

The delay in the improvement of trade balance is identified as the time lag that producers and consumers take to adjust to the new prices. Five different types of lags have been identified; recognition lag, decision lag, delivery lag, replacement lag and production lag (Junz and Rhomberg 1973). The trade balance may improve only after the realization of these lags.

\section{Background}

Sri Lanka has continuously recorded a trade deficit, which has worsened over the period (Chart 1). This deficit is mainly due to high oil prices and the increased demand for imports. On the other hand, the income elasticity of demand for primary commodities in world trade is less than unity, while the income elasticity of demand for manufactured goods is greater than unity. Hence, as world income grows the demand for primary commodities grows at a slower rate. However, if Sri Lanka grows at the same rate as the world economy, its

Chart 1 - Change in Trade balances in Sri Lanka, 1970-2008

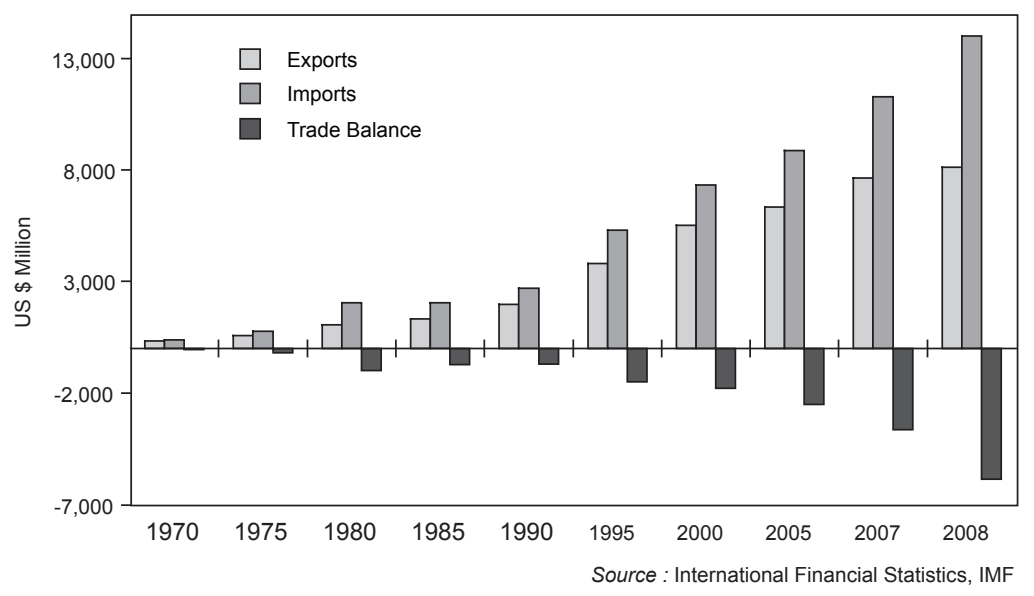


demand for manufactured goods grows at a faster rate. Therefore, as a consequence, Sri Lanka which specializes in the production of primary commodities suffers the difficulties in the trade balance.

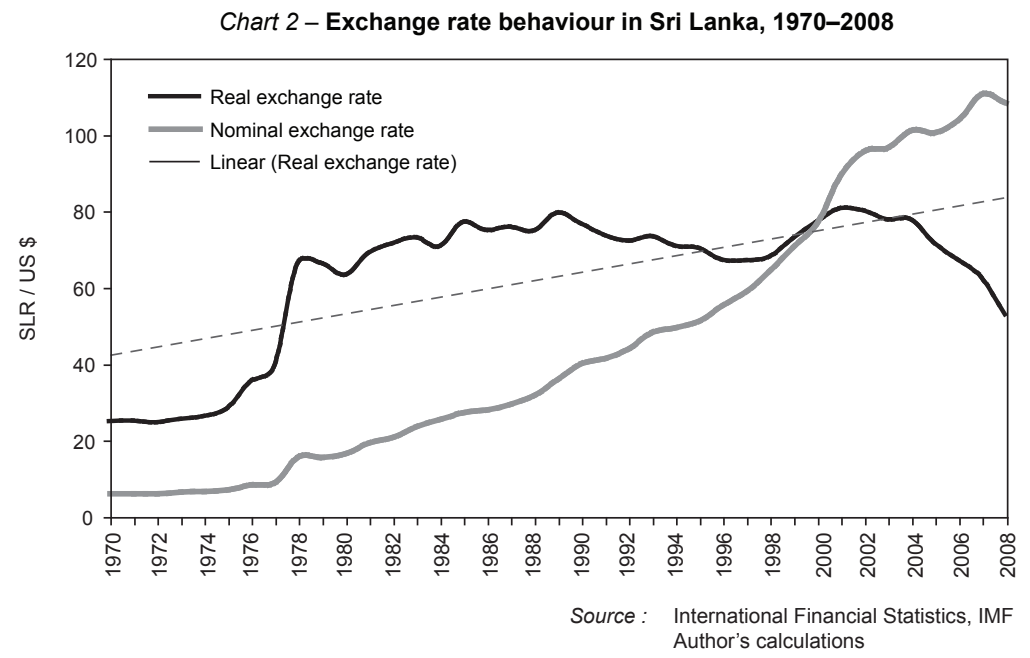

As shown in Chart 2, SLR has depreciated against the US dollar over this period both in real and nominal terms. During this period Sri Lanka has undergone several exchange rate regimes. In 1977, Sri Lanka liberalised its economy and moved to a managed floating exchange rate regime from a dual exchange rate regime. As a result, the real exchange rate has depreciated against US dollar by 69 per cent from Rs.39 in 1977 to Rs.66 in 1978. Further, in 2001 the country adopted a floating exchange rate system with Central Bank intervention.

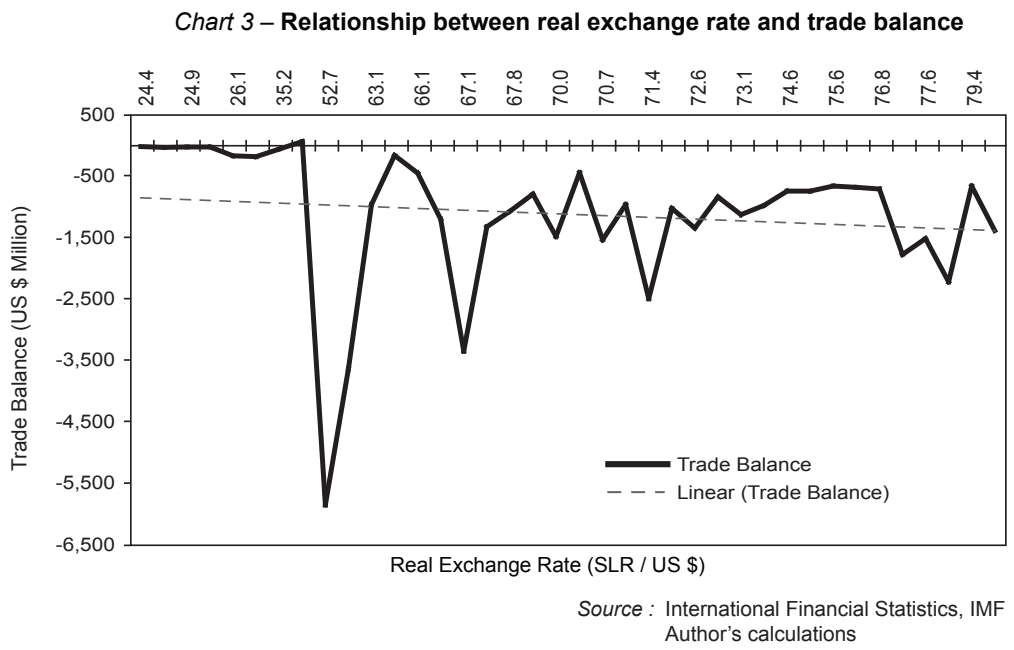


Chart 3 reveals that, in general, with the real depreciation of the SLR, the trade balance has deteriorated. Sri Lanka's main export items are textiles and garments, and primary goods including tea. Earnings from these items are relatively low due to high competition in the world market. In contrast, the country has to import crude oil, other intermediate and manufactured goods and defence related items which are essential. Hence, even though the exchange rate depreciates, Sri Lanka cannot limit the import of these essential goods. Therefore, with depreciation of the SLR, the trade balance has worsened.

\section{Literature Review}

The impact of currency devaluation on the trade balance (J-curve phenomenon) has been investigated by many researchers by using different econometric techniques and models. Most of the earlier studies used aggregate data, while recent studies have employed bilateral trade data. The use of aggregate data suppresses the actual movements of those variables involved. This is the main reason for moving to bilateral data. The empirical results of these studies are mixed. For instance, some studies have found no evidence for the J-curve effect (Narayan 2006; Bhamani-Oskooee and Wang 2006). Others have found that trade balance is improved in the long run (Bahmani-Oskooe and Ratha 2004; Arora et al. 2003). Most of the studies have found that, in the long run, a country's balance of trade would improve with one trading partner, while it can deteriorate with another with devaluation of the local currency (Bhamani-Oskooee and Wang 2006; Bahmani-Oskooee et al. 2005).

Bahmani-Oskooe and Ratha (2004), analysed the J-curve effect for the US bilateral trade with 18 major trading partners employing the autoregressive distributed lagged (ADRL) model. They concluded that, in the long run, devaluation of the US dollar improved the US trade balance with Austria, Denmark, Ireland, Italy, Japan, New Zealand, Sweden, and Switzerland. They found no evidence for the J-curve pattern in the short run. Nadenichek (2006), employed the structural vector error correction model to examine the behaviour of the US's trade balance with other G-7 countries. He found that the J-curve pattern exists for the bilateral trade balance between the US and the other G-7 countries.

According to Narayan (2006), China's trade balance with the US has improved not only in the long run but also in the short run with the depreciation of the Chinese RMB reflecting that the J-curve phenomenon does not hold. Bhamani-Oskooee and Wang (2006) have done a similar study for China and its 13 major trading partners. Their findings are compatible with Narayan's (2006) in the case of China's trade balance with the US. However, they found that in the short run, depreciation of the RMB has a significant impact in most cases.

More recently, Bahmani-Oskooee et al. (2006) tested the J-curve phenomenon employing quarterly bilateral data from 1970:Q1- 2001:Q3 for the UK and its 20 major 
trading partners. They came up with mixed results. In most cases, they found no support for the J-curve effect in the short run, while in the long run the UK's trade balance improved in only six cases (Australia, Austria, Greece, South Africa, Singapore and Spain). Only the UK's trade balances with Canada and USA support the J-curve phenomenon.

According to the findings of Bahmani-Oskooee et al. (2005), in the case of Australia, only the trade balance with Norway follows the J-curve phenomenon. They found that the depreciation of the Australian dollar has a positive and significant impact only on the trade balance with Denmark, Korea and New Zealand out of its 23 major trading partners.

Buluswar et al. (1996) analysed the effect of depreciation of the Indian rupee on its trade balance using stationarity and cointegration by employing aggregate data. He revealed that there is no evidence that India's trade balance follows the J-curve phenomenon and the trade balance has not even improved in the long run. In contrast, Arora et al. (2003), using bilateral trade data and employing the ARDL model for India's major trading partners found that its trade balance with Australia, Germany, Italy and Japan improved in the long run. Nonetheless, their findings are compatible with Buluswar et al. (1996) in the case of the J-curve phenomenon.

Narayan (2004) asserted that, with devaluation of the New Zealand dollar, its trade balance followed the J-curve pattern. Similarly, Bahmani-Oskooee and Kantipong (2001) found that Thailand's trade balance with the US and Japan also followed the J-curve pattern. Wilson (1999), examined the impact of currency devaluation between Malaysia and its two major trading partners (the US and Japan). He concluded that exchange rate depreciation does not have any significant impact on the bilateral trade balance and found no evidence for the J-curve effect. Further, Wilson (2001) argued that there is no evidence to suggest that the trade balance for Singapore and Malaysia with the USA and Japan follows the J-curve phenomenon, while Korea's trade balance with respect to both the US and Japan followed the J-curve phenomenon.

There has been little literature for the case of Sri Lanka. De Silva and Zhu (2004) examined the effect of SLR devaluation on the trade balance and GDP employing VAR and ECM analysis and using aggregate data. They found that currency depreciation has improved the Sri Lanka's overall trade balance.

Many researchers have attempted to find the J-curve effect especially for industrial countries, but only a few for developing countries. However, the literature does not reveal any attempt to examine the J-curve effect for Sri Lanka with its trading partners or at least as a trading partner of any other country concerned. Sri Lanka, as a developing country needs to have a better idea about the behaviour of the trade balance due to currency depreciation, as its currency depreciates continuously over the time. This is important, because if the trade balance is worsening, the government has to find solutions to finance this deficit. 
The objective of this study is, therefore, to examine the short-run and the long-run effects of depreciation of the Sri Lankan Rupee on its trade balance with six major trading partners; the United States, the United Kingdom, Japan, India, Hong Kong and Singapore using bilateral trade data. These countries have been selected as they accounted for more than 50 per cent of Sri Lanka's total international trade. Table 1 shows Sri Lanka's trade with these trading partners in 2007. The rest of the paper is structured as follows. Section 2 discusses the data and limitations, while the Model and the Methodology are given in Section 3. Section 4 discusses the empirical results and Section 5 presents the conclusion.

Table 1 - Sri Lanka's trade with major trading partners in 2007 (US\$ million)

\begin{tabular}{lcccc}
\hline \multirow{2}{*}{ Trading partner } & \multicolumn{2}{c}{ Exports } & \multicolumn{2}{c}{ Imports } \\
\cline { 2 - 5 } & \multicolumn{1}{c}{ Value } & $\%$ & Value & $\%$ \\
\hline Hong Kong & 65.80 & 1.04 & 724.81 & 6.41 \\
India & 515.28 & 8.12 & $2,610.14$ & 23.10 \\
Japan & 159.64 & 2.52 & 413.17 & 3.66 \\
Singapore & 80.19 & 1.26 & $1,118.54$ & 9.90 \\
United Kingdom & $1,018.04$ & 16.04 & 229.82 & 2.03 \\
United State & $1,969.98$ & 31.04 & 412.14 & 3.65 \\
\hline World & $\mathbf{7 , 7 4 0 . 4 3}$ & $\mathbf{1 0 0 . 0 0}$ & $\mathbf{8 , 8 6 3 . 0 0}$ & $\mathbf{1 0 0 . 0 0}$ \\
\hline & & Source : Direction of Trade Statistics, IMF.
\end{tabular}

\section{Data}

Quarterly bilateral time series data from 1996:Q1 to 2008:Q2 are used in this analysis. The data are obtained from CD-ROMs of the Direction of Trade Statistics and International Financial Statistics of the International Monetary Fund, except for quarterly GDP data for Sri Lanka. This has been obtained from the Statistical Monthly Bulletin of the Central Bank of Sri Lanka. The trade balance (TB) is defined as the ratio of Sri Lanka's exports to country $i$ (trading partner) over its imports from the same country. Hence, TB is expressed in unit free term and both real and nominal TBs are the same. Bilateral real exchange rate $(\mathrm{REX})$ is defined as $\left(N E X * P_{i} / P_{S L}\right)$, where $P_{i}$ is the Consumer Price Index $(\mathrm{CPI})(2000=100)$ in trading partner $i, \mathrm{P}_{S L}$ is the CPI $(2000=100)$ in Sri Lanka and NEX is the bilateral nominal exchange rate (period average) defined as the number of SLR per unit of trading partner $i$ 's currency. Consequently, an increase in REX reflects the real depreciation of the SLR with respect to trading partner $i$ 's currency. Quarterly 
GDP $(2000=100)$ data are used as real income both for Sri Lanka and the trading partner country.

In the case of Sri Lanka and India, quarterly GDP data are available only from 1996 and for Singapore from 1984:Q3. Hence, due to unavailability of data, the study has been limited to the period 1996:Q1 to 2008:Q2.

\section{Model and the Methodology}

First, particularly for time series data it is necessary to check for stationarity of the individual data. Then the ARDL model can be used to capture the short term dynamics.

\section{Test for Stationarity}

As a result of using non-stationary data, sometimes misleading results can be obtained through spurious regression. Therefore, to avoid this problem, this study first examines the stationarity of the logarithms of all individual variables using the unit root test. The most commonly used Augmented Dickey Fuller (ADF) test is employed to test the unit roots. If the individual variable is $Y_{t}$, then the ADF test is based on the following regression;

$$
Y_{t}=\rho Y_{t-1}+u_{t} ; \quad-1<\rho<1
$$

Where, $u_{t}$ is a white noise error term with mean zero and constant variance.

If, $\rho=1$, then $Y_{t}$ has a unit root and, therefore, it is non-stationary.

Equation (1) is often expressed in an alternative form as;

$$
\Delta Y_{t}=\left(\rho_{-1}\right) Y_{t-1}+u_{t}=\delta Y_{t-1}+u_{t}
$$

Where, $\delta=\left(\rho_{-1}\right)$ and $\Delta$ is the first difference operator.

After running the regression in (2), the hypothesis $H_{0}: \delta=0$ is tested against $H_{1}: \delta \neq 0$. If we fail to reject $H_{0}$, this implies that the variable is non-stationary in its level, and then the first difference of the variable is tested for unit roots. 


\section{Regression Model}

The trade balance model employed in this study follows the model used by BahmaniOskooee and Wang (2006). It is expressed in a log-linear format as in equation (3).

$$
\log T B_{i, t}=\alpha+\beta \log Y_{S L, t}+\gamma \log Y_{i, t}+\lambda \log R E X_{i, t}+\varepsilon_{t}
$$

Where,

$$
\begin{array}{ll}
T B_{i, t} & \text { - Trade balance between Sri Lanka and a trading partner country }(i) \\
Y_{S L, t} & - \text { Domestic income (GDP) } \\
Y_{i, t} & - \text { Income in trading partner } i \\
R E X_{i, t} & - \text { Bilateral real exchange rate between Sri Lanka and trading partner } i
\end{array}
$$

It is assumed that an increase in domestic income $\left(Y_{S L, t}\right)$ would increase the demand for imports and, therefore the trade balance will deteriorate. Hence, the estimated value of $\beta$ is expected to be negative. Similarly, the estimated value of $\gamma$ would be positive, if it is assumed that an increase in the trading partner's income would result in an increase in Sri Lanka's exports. Finally, an increase in the REX, that is real depreciation of SLR, would lead to increased exports and reduced imports. Therefore, the estimate of $\lambda$ would be positive.

Equation (3) gives the long run relationship among the variables. As the J-curve is a short-run phenomenon, it is necessary to incorporate the short-run dynamics into this model. This is done by adding the error correction terms into the model. This study employs the error correction model used by Engle and Granger (1987):

$$
\begin{aligned}
\Delta \log T B_{t}=\alpha & +\sum_{\mathrm{k}=1}^{\mathrm{n}} \omega_{k} \Delta \log T B_{t-k}+\sum_{\mathrm{k}=0}^{\mathrm{n}} \beta_{k} \Delta \log Y_{S L, t-k}+\sum_{\mathrm{k}=0}^{\mathrm{n}} \gamma_{k} \Delta \log Y_{i, t-k} \\
& +\sum_{\mathrm{k}=0}^{\mathrm{n}} \lambda_{k} \Delta \log R E X_{t-k}+\varepsilon_{t-1}+u_{t}
\end{aligned}
$$

Where, $\varepsilon_{t-1}$ is the lagged stationary residual of the equation (3). In equation (4), existence of cointegration among four variables can be confirmed either if $\varepsilon_{t-1}$ (lagged error correction term) retains a negative and significant coefficient or the residuals of equation (3) are stationary though all variables are non-stationary at their levels. However, Pesaran et al. (2001) have modified this model replacing $\varepsilon_{t-1}$ by linear combination of the 
lagged level of all four variables and have shown that for this model it is not necessary to test for unit roots. This is known as ARDL model and the model takes the form:

$$
\begin{aligned}
\Delta \log T B_{t}=\alpha & +\sum_{\mathrm{k}=1}^{\mathrm{n}} \omega_{k} \Delta \log T B_{t-k}+\sum_{\mathrm{k}=0}^{\mathrm{n}} \beta_{k} \Delta \log Y_{S L, t-k}+\sum_{\mathrm{k}=0}^{\mathrm{n}} \gamma_{k} \Delta \log Y_{i, t-k} \\
& +\sum_{\mathrm{k}=0}^{\mathrm{n}} \lambda_{k} \Delta \log R E X_{t-k}+\delta_{1} \log T B_{t-1}+\delta_{2} \log Y_{S L, t-1}+ \\
& +\delta_{3} \log Y_{i, t-1}+\delta_{4} \log R E X_{t-1}+u_{t}
\end{aligned}
$$

The $F$-test has to be carried out to check the validity of the inclusion of these variables into the model and to check whether these variables have long run relationships. The null hypothesis of $H_{0}: \delta_{1}=\delta_{2}=\delta_{3}=\delta_{4}=0$ (no cointegration) is tested against alternative $H_{1}: \delta_{1} \neq \delta_{2} \neq \delta_{3} \neq \delta_{4} \neq 0$ (cointegration). If the calculated $F$ statistic is greater than its critical value, then the null hypothesis is rejected. That is, variables are retained in the model and they are cointegrated. If variables are cointegrated, then the short run effect is given by the value and the sign of $\lambda$ 's. The J-curve phenomenon is supported if the first few $\lambda$ s have negative values and then positive values. The long run effect of the real depreciation of the SLR on trade balance is given by the estimated value of $\delta_{4}$, which is normalized on $\delta_{l}$.

\section{Empirical Results and Discussion}

Although it is not necessary to check for the unit roots to confirm the validity of the results, the ADF unit root test was carried out and the results are reported in Appendix A. This reveals that each variable is non-stationary at their levels (except for LogTBHK and LogTBUS), and they are stationary at their first difference, at 10 per cent significance level. Hence, the variables are integrated of order one.

Equation (5) was estimated using quarterly data over the period of 1996:Q1 to 2008:Q2. First, we check whether lag level of these variables are cointegrated and whether they should be retained in the model. For this purpose, the F-test was carried out and the joint significance of these variables was checked. Bhamani-Oskooee and Brooks (1999, cited in Arora et al. 2003: 1039) have concluded that 'the results of the F-test is sensitive to the number of lags imposed on the each first differenced variable'. Therefore, the $F$-test was carried out by imposing lags from one to six (applied the same lag for all variables 
and had to restrict maximum of six lags due to insufficient observations). The results of the $F$-test are reported in Table 2.

Table 2 - The results of $\boldsymbol{F}$-test for cointegration

\begin{tabular}{lcccccc}
\hline \multicolumn{1}{c}{ Trading Partner } & 1 Lag & 2 Lags & 3 Lags & 4 Lags & 5 Lags & 6 Lags \\
\hline Hong Kong & 4.81 & 3.25 & 3.80 & 3.16 & 2.33 & 2.51 \\
India & 7.45 & 2.51 & 2.93 & 2.04 & 3.08 & 2.40 \\
Japan & 3.61 & 4.57 & 4.26 & 2.93 & 1.74 & 1.61 \\
Singapore & 5.32 & 2.55 & 3.45 & 3.94 & 2.00 & 2.46 \\
United Kingdom & 2.80 & 2.34 & 4.05 & 2.25 & 1.26 & 6.66 \\
United State & 4.47 & 6.25 & 4.37 & 3.48 & 1.71 & 0.85 \\
\hline
\end{tabular}

It is clear from Table 2, that the calculated $F$-statistics are sensitive to the number of lags employed in the model. For instance, at one lag there are five cases greater than the critical value $^{2 /}$ which is 3.52 at 10 per cent significance level. Therefore, we reject the null hypothesis of no cointegration and it can be concluded that there is evidence for cointegration among these variables. Hence, these variables should be retained in the model. Nonetheless, at five lags none of the cases supports the existence of cointegration. Therefore, we pursue the Bhamani-Oskooee and Brooks (1999, cited in Bhamani-Oskooee and Kantipong 2001), and keep the lag level variables considering it as preliminary, because it can lead to results that would strongly support cointegration in the second step.

In the second step, the maximum of six lags were imposed on each of the first difference variables in equation (5), and then the best model for each country was selected, employing the Schwarz Bayesian criterion $(\mathrm{SBC})^{3 /}$. As we only consider the effect of real depreciation of the SLR on trade balance, only the short run dynamics relating to real exchange rate are reported in Table 3 , for simplicity.

2/ Critical value is taken from Pesaran et al. (2001), Table CI(iii) Case III, page 300.

3/ We can also employ the AIC and adjusted R squared as the model selection criterion and will get the different number of lags as optimal. These are given in the Appendix B. 
Table 3 - Estimated coefficients of the real exchange rate and error correction term based on SBC

\begin{tabular}{|c|c|c|c|c|c|c|}
\hline & \multicolumn{6}{|c|}{ Trading Partners } \\
\hline & Hong Kong & India & Japan & Singapore & $\begin{array}{l}\text { United } \\
\text { Kingdom }\end{array}$ & $\begin{array}{c}\text { United } \\
\text { State }\end{array}$ \\
\hline$\Delta$ Log REX & $\begin{array}{c}0.27 \\
(0.18)\end{array}$ & $\begin{array}{c}5.01 \\
(2.98)\end{array}$ & $\begin{array}{l}-0.80 \\
(0.54)\end{array}$ & $\begin{array}{c}1.49 \\
(0.94)\end{array}$ & $\begin{array}{c}0.02 \\
(0.01)\end{array}$ & $\begin{array}{c}3.56 \\
(2.03)\end{array}$ \\
\hline$\Delta \log \operatorname{REX}_{t-1}$ & & $\begin{array}{l}-5.25 \\
(1.50)\end{array}$ & $\begin{array}{l}-2.82 \\
(1.47)\end{array}$ & & $\begin{array}{c}0.87 \\
(0.41)\end{array}$ & \\
\hline$\Delta \log \operatorname{REX}_{t-2}$ & & $\begin{array}{l}-6.94 \\
(2.42)\end{array}$ & $\begin{array}{l}-3.00 \\
(1.87)\end{array}$ & & $\begin{array}{c}6.24 \\
(1.70)\end{array}$ & \\
\hline$\Delta \log \operatorname{REX}_{t-3}$ & & $\begin{array}{l}-4.73 \\
(1.96)\end{array}$ & $\begin{array}{l}-2.28 \\
(1.11)\end{array}$ & & $\begin{array}{c}7.19 \\
(2.14)\end{array}$ & \\
\hline$\Delta \log ^{R E X} t_{t-4}$ & & $\begin{array}{l}-1.44 \\
(0.75)\end{array}$ & $\begin{array}{l}-1.08 \\
(0.59)\end{array}$ & & $\begin{array}{c}8.43 \\
(2.59)\end{array}$ & \\
\hline$\Delta \log \operatorname{REX}_{t-5}$ & & $\begin{array}{l}-0.02 \\
(0.01)\end{array}$ & $\begin{array}{c}0.06 \\
(0.04)\end{array}$ & & $\begin{array}{c}5.32 \\
(1.98)\end{array}$ & \\
\hline$\Delta \log ^{R E X}{ }_{t-6}$ & & $\begin{array}{c}-2.67 \\
(-1.73)\end{array}$ & $\begin{array}{l}-0.41 \\
(0.27)\end{array}$ & & $\begin{array}{c}5.31 \\
(2.01)\end{array}$ & \\
\hline $\mathrm{EC}_{t-1}$ & $\begin{array}{l}-1.14 \\
(7.15)\end{array}$ & $\begin{array}{l}-0.08 \\
(0.26)\end{array}$ & $\begin{array}{l}-0.72 \\
(1.47)\end{array}$ & $\begin{array}{l}-0.40 \\
(2.77)\end{array}$ & $\begin{array}{l}-1.54 \\
(2.31)\end{array}$ & $\begin{array}{l}-1.38 \\
(9.38)\end{array}$ \\
\hline
\end{tabular}

Note: Figures in the parentheses are absolute values of t-statistics.

The results reported in Table 3, reveal that in the short run, there is no specific pattern for the trade balance between Sri Lanka and its trading partners in response to the change in real exchange rate. None of the cases supports the J-curve phenomenon. In the case of India, the trade balance first improved, and then deteriorated. With depreciation of the SLR, the trade balance between Sri Lanka and the United Kingdom has improved in the short run, but it is not significant up to two lags. However, there is no significant impact on Sri Lanka's trade balances with Hong Kong, Japan and Singapore with the depreciation of the SLR.

The long run coefficients are reported in Table 4 . In this case estimates of $\delta_{2}-\delta_{4}$ are reported after normalizing them on $\delta_{l}$. 
Table 4 - Estimated long run coefficient of the bilateral trade balance model based on SBC

\begin{tabular}{lcccc}
\hline \multicolumn{1}{c}{ Trading Partner } & Constant & $\log Y_{S L}$ & $\log Y_{\boldsymbol{i}}$ & $\log R E X_{\boldsymbol{i}}$ \\
\hline \multirow{2}{*}{ Hong Kong } & 1.35 & -0.54 & -0.26 & 0.06 \\
& $(0.21)$ & $(0.51)$ & $(0.27)$ & $(0.08)$ \\
India & 4.16 & -14.37 & 12.57 & 2.70 \\
& $(1.35)$ & $(2.79)$ & $(2.79)$ & $(2.88)$ \\
Japan & 11.75 & 0.04 & -2.67 & 1.09 \\
& $(0.44)$ & $(0.02)$ & $(-0.35)$ & $(0.59)$ \\
Singapore & -6.02 & -7.52 & 6.15 & 4.60 \\
\multirow{4}{*}{ United Kingdom } & $(0.94)$ & $(2.69)$ & $(2.12)$ & $(2.57)$ \\
& 54.67 & 34.32 & -39.26 & -6.18 \\
United State & $(3.45)$ & $(4.21)$ & $(4.19)$ & $(1.57)$ \\
& 2.22 & 0.41 & -0.44 & -0.31 \\
& $(0.96)$ & $(0.73)$ & $(-0.37)$ & $(-0.62)$ \\
\hline
\end{tabular}

Note: Figures in the parentheses are absolute values of t-statistics.

In Table 4, we can observe that a positive and statistically significant coefficient against the real exchange rate has existed only with respect to India and Singapore. Hence, in the long run, Sri Lanka's trade balance improved only with India and Singapore. All the other cases demonstrate that the real depreciation of the SLR does not play a significant role in determining the trade balance between Sri Lanka and each of the countries.

The expected sign has been received in the case of the trading partners' income, only for India and Singapore. This implies that an increase in income in India and Singapore will increase exports in Sri Lanka to those countries, and therefore increase the trade balance. The increase in income in the United Kingdom has a negative and significant impact on the trade balance between Sri Lanka and the United Kingdom. However, in the case of income in Sri Lanka, a negative and significant coefficient has been received only in the cases of India and Singapore confirming that the increase in Sri Lanka's income will increase the imports from those countries.

Finally, to verify the retaining of lag level variables, model (5) is re-estimated incorporating the error correction term. In doing so, we have calculated the lagged linear combination (denoted by $E C_{t-1}$ ) as included in equation (5) by using the estimates, calculated for $\delta_{1}-\delta_{4}$. Then the linear combination of the lagged level variables was replaced by $E C_{t-1}$. The model was re-estimated employing the optimal number of lags. According to Pesaran et al. (2001) a negative and significant coefficient in $E C_{t-1}$ denotes existence of cointegration among variables. These results are also reported in Table 3 , and can be observed that in most of the cases the coefficients of $E C_{t-1}$ are negative and highly significant. Hence, there is strong support for cointegration among these variables. 


\section{Conclusion and Policy Implications}

The impact of currency devaluation on the trade balance is an important characteristic that policy makers are interested in. With the introduction of the J-curve phenomenon many researchers have shown interest in finding the short run as well as long run effects on trade balance due to real depreciation of the exchange rate. Most studies have used aggregate trade data between a respective country and the rest of the world, while the most recent studies have employed bilateral trade data between a particular country and its trading partners. The findings of these studies are mixed.

In this study the impact of real depreciation of SLR on the trade balance in the short run and the long run have been examined, employing bilateral trade data between Sri Lanka and its six major trading partners. The methodology that has been used is based on the ARDL model advanced by Pesaran et al. (2001). The main conclusion that can be drawn is that in the short run, there is no specific pattern for the trade balance between Sri Lanka and its trading partners in response to the change in real exchange rate, and none of the cases supports the J-curve phenomenon. In the long run, only in the cases of India and Singapore has there been a positive and significant impact on trade balance with the depreciation of the SLR.

This study emphasises that Sri Lanka has to take action to improve its income from exports and reduce the expenditure on imports to over come the problem in the trade deficit. By improving the quality of exports, Sri Lanka can have a better price in the world market. On the other hand, adopting structural adjustments for exports to move from primary goods to manufactured goods would also be important as the income elasticity of manufactured goods is greater than unity. This would be an area for future research.

The study also reveals that both domestic and trading partners' real incomes are important determinants of Sri Lanka's trade balance. As domestic income has a negative impact on trade balance, policy makers have to consider proper policy measures to reduce expenditure on imports to reduce the trade deficit. This would also be an area for future research. 
Appendix A - Result of the Unit root test

\begin{tabular}{|c|c|c|}
\hline Variable & $\begin{array}{c}\text { Level } \\
\text { (with trend) }\end{array}$ & $\begin{array}{l}\text { First Difference } \\
\text { (with trend) }\end{array}$ \\
\hline $\operatorname{LogGDP}_{S L}$ & -1.9513 & -17.9740 \\
\hline $\operatorname{LogTB}_{H K}$ & -3.8471 & -7.5014 \\
\hline $\operatorname{LogGDP}_{H K}$ & -0.8427 & -12.6551 \\
\hline $\operatorname{LogREX}_{H K}$ & -0.4118 & -5.9120 \\
\hline $\operatorname{LogTB}_{I N D}$ & -0.3386 & -4.9809 \\
\hline $\operatorname{LogGDP}_{I N D}$ & -1.9082 & -15.4708 \\
\hline $\operatorname{LogREX}_{I N D}$ & -2.1855 & -6.0862 \\
\hline $\operatorname{LogTB}_{J P}$ & -2.5525 & -5.8218 \\
\hline $\operatorname{LogGDP}_{J P}$ & 0.1740 & -4.2001 \\
\hline $\operatorname{LogREX}_{J P}$ & -1.3980 & -5.0778 \\
\hline $\operatorname{LogTB}_{S I N}$ & -1.8911 & -5.8814 \\
\hline $\operatorname{LogGDP}_{S I N}$ & -0.1287 & -5.5238 \\
\hline LogREX $_{S I N}$ & 0.5911 & -4.4891 \\
\hline $\operatorname{LogTB}_{U K}$ & -1.7312 & -6.3795 \\
\hline $\operatorname{LogGDP}_{U K}$ & -1.5359 & -3.3450 \\
\hline $\operatorname{LogREX}_{U K}$ & -2.1989 & -4.5495 \\
\hline $\operatorname{LogTB}_{\text {US }}$ & -4.0992 & -5.3286 \\
\hline $\operatorname{LogGDP}_{U S}$ & -1.3297 & -2.7317 \\
\hline $\operatorname{LogREX}_{\text {US }}$ & -1.2217 & -4.4915 \\
\hline \multicolumn{3}{|l|}{ Critical Values } \\
\hline $1 \%$ & -3.5973 & -3.6019 \\
\hline $5 \%$ & -2.9339 & -2.9358 \\
\hline $10 \%$ & -2.6048 & -2.6059 \\
\hline
\end{tabular}


Appendix B - Values of AIC, SBC and Adjusted R-squared with different lags

\begin{tabular}{|c|c|c|c|c|c|c|c|}
\hline \multirow{2}{*}{ Trading Partner } & \multicolumn{7}{|c|}{ Number of Lags } \\
\hline & 0 & 1 & 2 & 3 & 4 & 5 & 6 \\
\hline \multicolumn{8}{|l|}{ AIC } \\
\hline Hong Kong & 0.11 & 0.20 & 0.37 & 0.20 & -0.30 & 0.00 & -0.59 \\
\hline India & 0.18 & -0.79 & -0.65 & -0.77 & -0.97 & -1.27 & -2.21 \\
\hline Japan & -0.23 & -0.15 & -0.51 & -0.72 & -0.73 & -0.95 & -1.39 \\
\hline Singapore & -0.01 & -0.16 & -0.11 & -0.08 & -0.33 & -0.56 & -1.04 \\
\hline United Kingdom & -0.55 & -0.49 & -0.32 & -0.48 & -0.52 & -0.51 & -2.03 \\
\hline United States & 0.23 & 0.32 & 0.18 & 0.27 & 0.29 & 0.24 & 0.09 \\
\hline \multicolumn{8}{|l|}{ SBC } \\
\hline Hong Kong & 0.44 & 0.71 & 1.05 & 1.05 & 1.00 & 1.22 & 0.81 \\
\hline India & 0.51 & -0.29 & 0.03 & 0.08 & 0.07 & -0.05 & -0.80 \\
\hline Japan & 0.10 & 0.35 & 0.17 & 0.13 & 0.30 & 0.27 & 0.01 \\
\hline Singapore & 0.32 & 0.34 & 0.57 & 0.78 & 0.70 & 0.65 & 0.36 \\
\hline United Kingdom & -0.22 & 0.01 & 0.36 & 0.37 & 0.52 & 0.71 & -0.63 \\
\hline United States & 0.56 & 0.82 & 0.86 & 1.13 & 1.33 & 1.46 & 1.49 \\
\hline \multicolumn{8}{|l|}{ Adjusted R-squired } \\
\hline Hong Kong & 0.51 & 0.51 & 0.46 & 0.57 & 0.64 & 0.58 & 0.61 \\
\hline India & 0.22 & 0.73 & 0.71 & 0.75 & 0.77 & 0.77 & 0.85 \\
\hline Japan & 0.31 & 0.30 & 0.55 & 0.64 & 0.64 & 0.66 & 0.65 \\
\hline Singapore & 0.38 & 0.52 & 0.48 & 0.48 & 0.59 & 0.60 & 0.59 \\
\hline United Kingdom & 0.42 & 0.42 & 0.36 & 0.48 & 0.48 & 0.40 & 0.79 \\
\hline United States & 0.66 & 0.66 & 0.72 & 0.71 & 0.70 & 0.67 & 0.53 \\
\hline
\end{tabular}




\section{References}

Arora, S., Bahmani-Oskooee, M. and Goswami, G., 2003. 'Bilateral J-curve between India and her trading partners'. Applied Economics, 35: 1037-41.

Bahmani-Oskooee, M., 1986. 'Determinants of International Trade flows: The case of developing countries', Journal of Development Economics, 20: 107-23.

, Economidou, C. and Goswami, G., 2006. ' Bilateral J-curve between the UK vis-à-vis her major trading partners', Applied Economics, 38:879-88.

, Goswami, G. and Talukdar, B., 2005. 'The bilateral J-curve: Australia verses her 23 trading partners', Australian Economic papers, 44(2):110-20.

and Kantipong, T., 2001, 'Bilateral J-curve Between Thailand and Her Trading Partners', Journal of Economic Development, 26(2): 107-17.

and Ratha, A., 2004. 'The J-curve dynamics of U.S. bilateral trade', Journal of Economics and Finance, 28: 32-38.

and Ratha, A., 2004.'The J-Curve: a literature review', Applied Economics, 36:1377-398.

and Wang, Y., 2006. 'The J-curve: China verses her trading partners', Bulletin of Economic Research, 58(4): 323-43.

Boyd, D., Caporale, G. and Smith, R., 2001. 'Real Exchange Rate Effects on the Balance of Trade: Cointegration and the Marshal-Lerner Condition', International Journal of Finance and Economics, 6(3): 187-200.

Brahmasrene, T. and Jiranyakul, K., 2002. 'Exploring Real Exchange Rate Effects on Trade Balance in Thailand', Managerial Finance, 28:16-27.

Brada, J., Kutan, A. and Zhou, S., 1997. 'The exchange rate and the balance of trade: The Turkish experience', The Journal of Development Studies, 33(5): 675-92.

Buluswar, M., Thompson, H. and Upadhyaya, K., 1996. 'Devaluation and the trade balance in India: stationarity and cointegration', Applied Economics, 28:429-32.

De Silva, D. and Zhu, Z., 2004. 'Sri Lanka's Experiment with Devaluation: VAR and ECM Analysis of the Exchange Rate Effects on Trade Balance and GDP', The International Trade Journal, XVIII(4): 269-301.

Gomes, F. and Paz, L., 2005. 'Can real exchange rate devaluation improve the trade balance? The 1990-1998 Brazilian case’, Applied Economics Letters, 12: 525-28. 
Junz, H. and Rhomberg, R., 1973, 'Price Competitiveness in Export Trade among Industrial Countries', The American Economic Review, 63(2):412-18.

Magee, S., 1973. 'Currency Contracts, Pass-Through, and Devaluation', Brookings Papers on Economic Activity, 1973(1): 303-25.

Nadenichek, J., 2006. 'The J-curve Effect: An Examination using a Structural Vector Error Correction Model', International Journal of Applied Economics, 3(2): 34-47.

Narayan, P., 2004. 'New Zealand's trade balance: evidence of the J-curve and granger causality', Applied Economics Letters, 11: 351-54.

, 2006. 'Examining the relationship between trade balance and exchange rate: the case of China's trade with the USA', Applied Economics Letter, 13: 507-10.

Pesaran, M., Shin, Y. and Smith, R., 2001. 'Bounds Testing Approaches to the Analysis of Level Relationships', Journal of Applied Econometrics, 16:289-326.

Sing, T., 2004. 'Testing J-curve hypothesis and analyzing the effect of exchange rate volatility on the balance of trade in India', Empirical Economics, 29:227-45.

Wilson, P., 1999. 'Exchange Rates and the Trade Balance: the case of Malaysia from 1970 to 1996', Malaysian Journal of Economic Studies, 36(2): 1-15.

, 2000. 'Exchange Rates and the Trade Balance: Korean Experience 1970 to 1996', Seoul Journal of Economics, 13(2): 135-63.

, 2001. 'Exchange Rates and the Trade Balance for Dynamic Asian Economies -

Does the J-curve Exist for Singapore, Malaysia, and Korea?', Open Economies Review, 12(4): 389-413. 